\title{
Critical Issues in Sustainable Tourism Development in Romania: Challenges and Lessons For Kenya \\ 10kech R.N and ${ }^{2}$ Alexandru Nedelea
}

\begin{abstract}
Sustainability as a concept involves a number of different strands. Environmental, ecological and economic factors assume that it is applicable in the technical sciences, whereas social and political factors relate to power and values. Within these strands, questions of scale, family, community, region, timescale, project life, indefinite and so on are critical elements. Without any notable exceptions the Romanian specialists and the foreign ones agree upon the fact that the Romanian tourism potential could compete with the touristic supply of any other country in the world thus significantly contributing to the income growth. Today, the Romanian hospitality industry confronts itself with problems such as: the decline of the internal and external touristic demand, an old touristic product, the low standard in the services which do not satisfy the tourists 'expectations, the payment and too high prices compared to the quality of the services, an insufficient promotion. Kenya on the other hand is also faced with challenges in the promotion of other aspects of tourism products other than wildlife and the Maasai. This paper hence seeks to redress the critical issues in sustainable tourism development in the two countries and in so doing, hopes to outline the way forward in the $21^{\text {st }}$ century.
\end{abstract}

Key words: sustainable development, Romania, Kenya, tourism, regional development

\section{Introduction}

The concept of "development"
indicates a major change in the approach of those problems concerning the human development by assuring a dynamic balance between the components of the natural capital and the socio-economical systems. The strategies of sustainable development emphasize the interdependence between the local and the global, between the already developed countries and the ones following this course, underlining the necessity of cooperation within economical, social and environmental sections. The tourism sector constitutes one of the most important sources of wealth of nations regardless of their level of development. For many developing countries, in particular the least developed countries (LDCs), small economies and islands states; tourism is probably the only economic sector, which provides concrete and quantified growing trading opportunities, and therefore, it is for them one of the fundamental pillars of their economic development.

The forecasting study conducted by the WTO to examine how the tourism industry, and particularly tourism demand, is likely to evolve in the next twenty years provides a valuable framework to the discussion about sustainability in tourism (WTO, 2001). The results indicate that international tourist arrivals are likely to increase at an annual average rate of around 4\%, to reach nearly 1.5 billion by the year 2020 that is almost three times the number of arrivals recorded in 1998. The impacts that these hundreds of millions of tourists moving around the globe may cause upon the natural environment and upon the social and cultural fabrics of host communities need to be anticipated, carefully studied, prevented to the extent possible and continuously monitored if tourism is to effectively contribute to sustainable development. This needs to be clearly understood because there are complex and close relationships between tourism and the natural and cultural environments.

In line with the paradigm of sustainable tourism it is believed that negative effects can be avoided or minimized if tourism development is thoroughly planned and controlled (Parker and Khare, 2005; Watson, 1996). The emergence of the concept of sustainable development marked a convergence between economic development and environmentalism. This convergence was officially illustrated at the Stockholm Conference on Humans and the Environment in 1972, the first of a series of major UN conferences on global issues related to the environment. The conference promoted the concept of eco-development whereby cultural, social and ecological goals were integrated with development. The philosophy of this concept was, small is beautiful, typifying the eco-development approach and this was 
subsequently incorporated into the strategic plans of many industries, including tourism.

The negative impact of tourism, including its growing threat to the aims and practice of many conservations bodies was becoming better and more widely understood, in developed and developing countries alike. "The green tourism" is especially used by those who have something to sell. In many people's mind it appears to mean the same as "rural tourism". Another popular term is "alternative tourism" which conveys" some meaning of difference to mainstream practice, but doesn't include any sense of the activity itself, or what its principles may be. Another label that is sometimes used is "responsible tourism". This to our mind has a rather sanctimonious and exclusive ring to it, and implies that all other tourism is totally irresponsible.

The term "ecotourism" is a more meaningful one (Eagles, 1995; Fennell, 1999). It's most commonly applied to the type of holiday which enables tourists to have much more direct contact with nature than usual (Buckley, 1994; 2001). Ecotourism generally means a visit to one of the more remote areas, where you can observe animals and birds in their natural habitat, examine the flora and fauna at first hand, or have direct, unmediated contact with a local community. Since, tourism plays an important role in improving standards of living and rising people above the poverty threshold, it has become a platform to transform the vicious circles of misery, into virtuous circles towards productive transformation, welfare and improvement of human capital. Tourism not only provides material benefits it also brings cultural pride, a sense of ownership and control through diversification and reduced vulnerability.

Tourism should be assessed objectively against other opportunities, to overcome poverty in tourism destinations of developing countries. Though, to maximize the benefits of tourism, the existing uneven distribution of benefits among nations that is threatening the economic, social, and environmental sustainability of tourism in many developing countries, have to be overcome. Yet, the 49 LDCs accounts today for only less than 1 percent of international tourist arrivals and an approximately 0.5 percent of international tourism receipts. This acute imbalance is being accentuated by the dependence of tourist destinations on external travel distribution networks, and the anticompetitive behaviour of some tourism operators at worldwide scale. To a great extent, such a situation is responsible for the loss of potential remuneration of developing countries and in particular in LDCs. Mass tourism can destroy the environment, the economy, the host country and its people, even the tourists themselves. Sustainable development is the development that meets the needs of the present without compromising the ability of future generations to meet their own needs.

The effect of our continuing misuse of the earth' resources, the part played by tourism in this process, the links between development and tourism are very important issues to be solved. Tourism is at the present time the largest income generator of the world economy. Export revenue amounted to an estimated US\$ 532 billion, surpassing all the other international trade categories. International tourism totalled to US\$ 441 billion and the international transport of passengers US\$ 91 billion, which corresponded to 7.9 and 1.3 per cent respectively of worldwide exports of good and services. The proper functioning of the tourism economy is linked to that of many other related economic activities, which accounts for the importance of its economic, social and environmental sustainability.

As a matter of fact, the extent to which the business operations of international tourism, backward and forward are linked with other sectors will determine the level of performance and profitability of tourism, the extent of multiplier and spill over effects, and the retention of value added, i.e. the leakage effect. The sectors producing goods and services are linked backwards with tourism in catering for the needs of tourists and tourism operators, e.g. agriculture and food-processing industries, and other manufacturing industries providing furniture, construction materials and other articles required by tourism establishments. Similarly, many other services, such as transport, business services, financial services, professional services, construction design and engineering, environmental services, security services and government services, also ensure the efficient performance of tourism operators. Some of these sectors are also crucial for the proper linkage of tourism with foreign markets (forward linkages) 
because they constitute the platforms for "taking off" and for keeping the national tourism providers fully integrated with international tourism flows.

Many developing countries have found it important to improve the linking of tourism (forward and backward) with the other sectors of the economy as one of the foundations of tourism development policies, so as to capitalize on the benefits of the globalisation and internationalisation of markets. Successful experiences of small economies, attest to the vital importance of the proper linkage of tourism with the rest of the economy, in their capacity of retaining value added, e.g., reducing leakages. Despite developing countries efforts to develop the most suitable domestic policy environment, the economic sustainability of tourism is being undermined by external factors beyond their control, notably the predatory behaviour of integrated suppliers which enjoy a dominant position in the originating markets of tourism flows. As a modality of international commerce, tourism involves not only inflows of foreign financial resources but also outflows, referred to herein as "leakages."

When they exceed specific levels, these outflows can significantly neutralize the positive financial effect of international tourism. Leakage is the process whereby part of the foreign exchange earnings generated by tourism, rather than being retained by touristreceiving countries, is either retained by tourist-generating countries or repatriated to them in the form of profits, income and royalty remittances, repayment of foreign loans, and imports of equipment, materials, capital and consumer goods to cater for the needs of international tourist and overseas promotional expenditures.

\section{Development of the Romanian Sustainable Tourism}

Without any notable exceptions the Romanian specialists and the foreign ones agree upon the fact that the Romanian tourism potential could compete with the touristic supply of any other country in the world thus significantly contributing to the income growth. Let's remember that in the $60 \mathrm{~s}$ Romania was a successful touristic destination especially due to the Black Sea. The regress started with the communist national isolation. Its fall has not brought the supposed good changes and today the tourism Romanian industry is measured by a series of parameters which explain its peripheral position in international context. The economic, social and political context of the period after 1990 has not been one that contributed to the Romanian tourism development. Today, the Romanian hospitality industry confronts itself with problems such as: the decline of the internal and external touristic demand, an old touristic product, the low standard in the services which do not satisfy the tourists' expectations, the payment and too high prices compared to the quality of the services, and insufficient promotion. Moreover after 1989 because of the population low income level a restructuring of the consumption priorities took place and this did not favour tourism (Nedelea, 2003a).

Among the countries from the East and Central Europe, Romania is considered the country which possesses the richest and most varied natural touristic resources created by man and this gives a great disposability for tourism. The general secretary of the International Tourism Organization states that: "Such a country which owns the Danube Delta, the Black Sea, The Bukovina monasteries could live and prosper from tourism only." Unfortunately, as a Horwath British firm specialized in consultancy has pointed out, Romania is, for the foreign tourists "an expired touristic product, an inadequate offer for time spending, which reflects the lack of investment." Thus Romania has reached an expensive touristic destination. The Romanian international touristic demand registers a diminution tendency due to some causes such as: the low quality level of the offered touristic services, the touristic services non-diversification, the reduced amusement possibilities.

The internal touristic demand registered a diminution tendency caused by the low sales power of the population and a lack of correlation between the practised tax levels and the service qualities. Some of the possible ways of tourism relaunching constitutes the elaboration of some efficient marketing strategies and politics starting from a marketing environment analysis. In order to conceive and promote a competitive Romanian touristic product the adoption of a quality rise strategy is essential. In Romania the Q Mark National Application Program was conceived. On the local market we notice the horizontal integration (concentration) phenomenon 
manifestation which is concretized in some hotel chains development (Nedelea, 2003b).

\section{Issues of Regional Development}

The concept of a region can be quite complex, as regions are often not static but evolve as conditions warrant. Regional development is a new concept that aims at stimulating and diversifying economic activities, stimulating investments in the private sector, contributing to decreasing unemployment and, last but not least, a concept that would lead to an improvement in the living standards. In order to apply the regional development strategy, eight development regions were set up, spreading throughout the whole territory of Romania. Each development region comprises several counties. Regional development policy is an ensemble of measures planned and promoted by the local and central public administration authorities, having as partners different actors (private, public, volunteers) in order to ensure a dynamic and lasting economic growth, through the effective use of the local and regional potential, in order to improve living conditions (Dolipschi, 2006).

The main areas regarded by the regional policies are: development of enterprises, the labor market, attracting investments, development of the SMEs sector, improvement of infrastructure, the quality of the environment, rural development, health, education, culture. Rural development has a very distinct place within regional policies, and deals with the following aspects: removal/reduction of poverty in the rural areas; balancing of economic opportunities and social conditions between the urban and rural areas; stimulating local initiatives; safeguarding of the spiritual and cultural patrimony. The development region, constituted as a freewill association of neighbour countries represents the implementation and assessment framework of the regional development policy.

The development region is not a territorialadministrative entity and does not have legal personality. The main objectives of the regional development policies are as follows:

- to reduce the existing regional disparities, especially by stimulating the well-balanced development and the revitalization of the disadvantaged areas (lagging behind in development) and by preventing the emergence of new imbalances;
- to prepare the institutional framework in order to comply with the integration criteria into the EU structures and to ensure access to the financial assistance instruments (the Structural Funds and the Cohesion Fund of the $\mathrm{EU})$;

- to correlate the governmental sector development policies and activities at the level of regions by stimulating the inter-regional, internal and international, cross-border cooperation which contributes to the economic development and is in accordance with the legal provisions and with the international agreements to which Romania is a party;

The principles that the elaboration and the application of the development policies are based on are:

- Decentralization of the decision making process, from the central/governmental level to the level of regional communities;

- Partnership among all those involved in the area of regional development;

- Planning - utilization process of resources (through programs and projects) in view of attaining the established objectives;

- Co-financing - the financial contribution of the different actors involved in the accomplishment of the regional development programs and projects.

What is important to note in terms of regional development is the extent to which a tourism region is linked into the domestic and international tourism market, as revealed in the following comment. 'The interactions between capitalist systems, localities, and regions (the local-global linkages) define the regions and its processes of economic development.' The various institutions of the state can have an impact on how tourism is used as a vehicle for regional development. The main institutions of the state include the central government, administrative departments, the courts and judiciary, enforcement agencies, other levels of government, government business enterprises, regulatory and assistance authorities and a range of semi-state organization.' 


\section{Cross Border Co-operation Programs in Romania}

As National Coordinator of the cross border co-operation programs, the Ministry of Development and Prognosis focuses on the involvement of the local actors representing the countries from the border region with Bulgaria and Hungary in the preparation of the projects proposed to be financed, and on the co-ordination between the local community needs and the provisions of the National Development Plan (Nedelea, 2005; Stucki, 1992). According to the short, medium and long-term priorities agreed by the Joint Cooperation Committees established for the borders with Bulgaria and Hungary, project proposals in the following fields have been and will be financed from EU Phare funds:

- Improvement of the existing transport infrastructure on the Trans-European Corridors IV (Dresden - Constanta Thesaloniki - Istanbul) and IX (Baltic Sea - Aegean Sea, on the sector Bucharest - Dimitrovgrad);

- Promotion of the environmental protection, especially water resources management;

- Free flow of persons, services and goods through the border crossing points;

- Socio-economic regional development through the Small Projects Fund.

Having in view the European Commission Regulation No. 2760/1998 already entered in force regarding the crossborder co-operation, at least $90 \%$ of the funds allocated per year for a border region will be used for major investment projects as follows: a min. of 2 MEuro (Phare funds) plus 25\% national co-financing from the total investment value. We would also like to mention that in accordance with the common agreements, both committees set-up with the Bulgarian and Hungarian partners decided to increase gradually, starting with the year 2000, the importance given to small scale projects by allocating more funds on annual basis, up to $10 \%$ from the total available/allocated funds (a max. of 800.000 Euro for the RomanianBulgarian border region and a max. of 500.000 Euro for the Romanian-Hungarian border region). These projects will be proposed exclusively by local actors within the Small Projects Fund. Looking back on the achievements of the Phare cross-border cooperation programs and Phare Credo program in Romania for the period 1996-2000 in all the 18 counties from the border region with Hungary, Bulgaria, Moldova and Ukraine it was highlighted that the total amount of the Romanian project is in a total of 45.2Meuro: Phare funds: 29.2 MEuro and national cofinancing: 16 MEuro, representing 35.5\% from the total value of the projects (Nedelea, 2004; Bausch, 2000). For the next two years the following funds will be available for Romania:

- 8 MEuro for the counties from the Romanian-Bulgarian border region;

- 5 MEuro for the counties from the Romanian-Hungarian border region

\section{Challenges and Lessons For Kenya (Ecotourism Aspect)}

Kenya is still one of the foremost tourist destinations in Africa. Tourism in Kenya is mainly based on natural attractions which include wildlife in its natural habitats as well as idyllic beaches. Game viewing is a very popular pursuit since most visitors to Kenya are predominantly interested in seeing "the big five" not to mention other lesser and unique game the Africa's savanna and forests. The main challenge for the Kenyan tourism sector is environmental management. Ecotourists have high levels of environmental conscience. Their internal environmental philosophy dictates that nature must be protected and celebrated within a natural context, resulting in a superabundance of environmental protection rules, policies and laws. According to Casagrandi and Rinaldi (2002) the quality of the environment $E(t)$, in the absence of tourists and capital, is described by a classical logistic equation:

$\dot{E}(t)=r E(t)\left[1-\frac{E(t)}{K}\right]$

Where the net growth rate $r$ and the carrying capacity $K$ are influenced by all activities except those related to tourism industry. In other words, $\mathrm{K}$ is not the quality of the environment in unrealistic (pristine) conditions, but, instead, the quality of the environment at the equilibrium in the presence of all civil and industrial activities (except for tourism) characterising the site under study. If tourists and facilities impact negatively on the environment, the complete dynamics of $E(t)$ is: 


\section{K}

Where $D(T(t), C(t), E(t))$ represent the flow of damages induced by tourism. Generally, this flow is positively correlated with tourists and capital. Moreover, the damage is higher when the environment is still unexploited. The simplest functional form consistent with these properties is the following:

$\mathrm{D}=\mathrm{E}(\beta \mathrm{C}+\gamma \mathrm{T})$

Where two parameters $\beta$ and $\gamma$ are positive. For example heating of hotels, which impacts on air pollution, has a first component which is basically independent upon the number of tourists (heating the hall, cafeteria and restrooms) and a second component which is proportional to the number of visitors (heating the bedrooms).

The same is true for many other touristic facilities, like ski lifts and discothèques (noise pollution), bus services (air pollution), artificial snow facilities (downstream water pollution) and many others. Exceptionally $\beta$ and $\gamma$ can be negative, for example, when high reclamation efforts are associated with tourism development. This means that if $\mathrm{T}$ and $\mathrm{C}$ would be kept constant, the environment would still be described by a logistic equation:

with

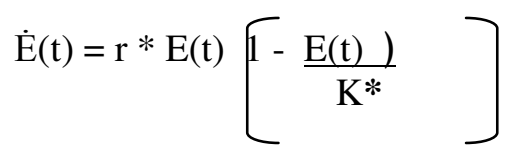

$$
\begin{aligned}
& r^{*}=r\left[1-\frac{\beta C+\gamma \mathrm{T})}{r}\right] \\
& \mathrm{k}^{*}=\mathrm{k}\left[\frac{-\left(\frac{\beta C+\gamma \mathrm{T})}{r}\right]}{\mathrm{r}}\right]
\end{aligned}
$$

In other words, if $\beta$ and $\gamma$ are positive, tourism activities $(\mathrm{C}$ and $\mathrm{T}$ ) reduce the carrying capacity and the net growth rate of the environment in the same proportion. The impacts of ecotourism depend on what ecotourism is. Definitions and characteristics have been reviewed extensively by several authors (Casagrandi and Rinaldi, 2002). The critical issue, however, is that ecotourism should involve deliberate steps to minimize impacts, through choice of activity, equipment, location and timing, group size, education and training, as well as operational environmental management. Under these circumstances, which are regrettably more of an ideal than a practical reality in most cases, the impacts of ecotourism should therefore be those of nature tourism and recreation which incorporates best practice environmental management. Biodiversity and environmentally intact lands form the basis of ecological stability. But this has already been severely affected by industrialization, urbanization, unsustainable agricultural practices and mass tourism. While ecotourism sounds comparatively benign, one of its most serious impacts is usurpation of "virgin" territories national parks, wildlife sanctuaries and other wilderness areas which are then packaged as green products for ecotourists. Hence, with the tremendous expansion of commercialized ecotourism, environmental degradation, including deforestation, disruption of ecological life systems and various forms of pollution, has in fact increased. Even its proponents concede that ecotourism is far from a panacea for environmental destruction.

The Masai Mara and Amboseli National Parks are both excellent examples of ecological disasters arising from tourism (Sindiga, 1999). In both the areas, lodges and camps have heavily deforested the small riverine forests that existed with their hunger for firewood for cooking and heating. The number of motor vehicles crisscrossing the park areas keeps growing as tour drivers search for rare animals such as lions and rhinos. An unsightly network of roads and tracks for "game drives" disrupts the grass cover, with serious consequences for plant and animal species. Often overlooked is the fact that ecotourism is a highly consumer-centered activity catering to the lifestyles of the new urbanized middle-class societies. In their search for untouched or authentic places, young and adventurous travelers open destinations off the beaten track, accelerating the pace of social and environmental decay in host communities. But any commercial venture into unspoiled, pristine natural places with or without the "eco" prefix is a contradiction in terms.

To generate substantial revenue, whether from foreign exchange, tourism business, local communities or conservation, the number of tourists must be high, which inevitably means greater pressures on the environment. Many East African parks are also 
mismanaged and are deteriorating rapidly. Several authors (Anderek, 1995; Hall \& Lew, 1999; Hardy et al., 2002; Honey, 1999; McLaren 1998; Mowforth and Munt, 1998; Stabler; 1997; Telfer, 2002) realized that recent efforts to rearrange existing mass tourism into ecotourism have failed due to a general reluctance to limit the growth of tourism; lack of controls and sustainability; and lack of thorough examination on the environmental impacts of tourism, including the impact of environmental resource utilization, the consumptive nature of tourism, and its continuous discharge of pollutants through increased road and air traffic. There are broader environmental issues relating to the impacts of long-distance air and ground travel to and from an ecotourism destination, and to accommodation in urban hotels before and after an ecotour.

As elsewhere in Africa, tourism accommodation and wildlife viewing facilities in Kenya are established without local or regional master plans. In the Maasai Mara case, several lodges were constructed at the same time without much planning. These facilities have led to a very large number of tourists into a relatively small national reserve with serious impacts to the environment. Many of the protected areas are located in semi-arid lands with delicate ecologies. Other problems are animal harassment by tourist vehicles.

Despite existing regulations on park use, tour drivers chase selected wild animals, especially the predators such as lions, leopards and cheetahs, by off-road driving so as to satisfy their visitors' desire for close-up photographic opportunities. Over 50\% of visitor time is spent on only 5 animal species (big five) namely, lion, leopard, buffalo, elephant and rhino (Honey, 1999). As a result of the animal harassment, lions are unable to mate, and cheetahs which are diurnal hunters cannot look for food, even those which have a kill are forced to abandon it. Besides, off-road driving tramples lion cubs. In general, the carrying capacities of a number of parks have been exceeded. In Maasai Mara, just like in a number of other conservation areas, ecotourism's impacts have reduced wildness of scenery and are affecting the abundance of wildlife in their natural setting, the very virtues that the visitors are looking for in their gaze of the reserve. The Recreation Opportunity
Spectrum (ROS) framework allows for the management of various recreation experiences based on access, other non-recreational uses, site modifications, social interaction, acceptability of visitor impacts and acceptable levels of management. The Limits of Acceptable Change (LAC) process focuses on wilderness planning with explicit objectives and opportunity classes for different management approaches.

Management decisions focus on bringing back or maintaining the desired state for each opportunity class. The Visitor Impact Management (VIM) model is a planning framework for controlling or reducing undesirable impacts of recreational use. It is a step-by-step process for identifying impacts, their causes and how effective management can be used as a management tool for localized impacts. Another approach is to develop a framework that assists managers in devising indicators of acceptable environmental change by first classifying natural attractions and then selecting appropriate indicators for management (Ward et al., 2002). Hence from the foregoing discussions with the Romania tourism there are a lot of challenges and lessons for Kenya which are outlined below.

- A tourism policy is required at the national, regional and local levels. Tourism can no longer grow as a result of spontaneous, individual and uncoordinated actions by isolated actors, governments at all levels are required to formulate policies for its orderly development;

- The tourism policy should be the result of a participatory process, in which all interested parties, and particularly the local community, are involved;

- A comprehensive approach should be adopted, whereby all aspects of tourism development are considered in the planning process, including the tourist attractions, the basic infrastructure and services, accommodation and catering facilities, transportation, management aspects, human resource development, as well as the institutional elements;

- Similarly, an integrated approach is required. Tourism cannot be planned in isolation instead, it must be part of the overall development efforts of a country or area while local tourism plans must be integrated into national tourism strategies; 
- Environmental impact assessment techniques must be applied from the very beginning of any tourism development plan or project. Appropriations should be made to ensure that the cost of avoiding any potential damages to the environment as a result of such development has been taken into account in the economic and financial calculations;

- Tourism companies and destinations must be managed with the environment and the local community in mind. This needs appropriate environmental and social science training of tourism managers and employees at all levels, to enable industrywide application of environmental management systems and corporate social responsibility criteria in all tourism companies;

- The management of tourism at both the company and the destination levels requires continuous monitoring, particularly with respect to environmental and social variables. Monitoring allows managers and public authorities to take corrective actions when needed and before negative impacts become irreversible; and

- As an indispensable element for the above monitoring process, indicators for sustainable tourism must be developed and introduced as a normal practice at all tourism destinations, following the methodology developed and tested by WTO. Indicators also serve to guide consumers about the environmental and social quality of the destination, and are good benchmarks to stimulate destinations to compete on sustainability grounds rather than on price.

Kenya is uniquely attractive as an ecotourism destination due to its biological, ecological and cultural diversity, but the region also faces some monumental societal challenges. People are affected by poverty and HIV/ADS. Developing a responsible enterprise founded on the three pillars of environmental protection, community development and economic gains provides a possible solution, on a local level, to some of Kenya's most pressing problem. In order to be effective, ecotourism enterprises must be sustainable and provide for continuing benefits. Communities must be able to take part in the ongoing development and management of the enterprise, and the protection of the ecology must not be compromised. Economically, if the enterprise is not sustainable then there will be no enterprise at all. An enterprise developed without due consideration of the critical success factors will not be sustainable.

\section{Conclusions}

Destinations in Africa enjoy a privileged position in relation to the major tourist generating markets due mainly to their unique features, history as well as a wide range of products on offer. The strong awareness for conservation of the environment and the demand for exoticism by potential travelers translate into increasing demand by an ever growing number of foreign visitors. Accordingly, there is need for destinations in Africa to co-operate more closely in areas of product development, research, manpower development and training as well as exchange of tourism experts and tourism information. It is also necessary to harmonize travel formalities withing the region so as to encourage free flow of visitors and maximization of benefits accruing from tourist intercations within the region. Indeed such close co-operation can be forged and enhanced within the framework of the existing regional economic groupings such as (Common Market for Eastern and Southern Africa (COMESA), Preferential Trade Area (PTA), SADC, East Africa Co-operation and The Indian Ocean Rim) and their role in positioning Africa to be a major force in the envisaged tourism growth. In the development, promotion and marketing of our respective destinations we should bear in mind the complementary nature of our products within the region. Secondly, although by and large the countries within the region are destination countries rather than tourist generating countries, there is a vast market for intra-regional tourism, which has not yet been fully tapped.

Most of Kenya's and Romania's ecosystem still remains intact and unspoilt thus providing a strong basis for a sustainable tourism development. All that is required is proper planning and management of available resources. It should be borne in mind that sustainable tourism cannot thrive if we do not take care of our fragile environment. In this context, therefore, we should always remember the cardinal point that we shall be able to conserve our fragile environment and biodiversity for the benefit of mankind. To this 
end there is therefore, an urgent need to put the necessary legislations and codes of conduct in place so as to ensure balanced development of tourism in African tourist destinations. Exchange of information and experience

\section{References}

Anderek, K.L. (1995), "Environmental Consequences of Tourism: A Review of Recent Research". In S.F. McCool and A.E.Watson (eds.) Linking Tourism, the Environment and Sustainability. US Forest Service Intermountain Research Station. General Technical Report INTGTR-323. Ogden, Utah.

Bausch, T.H. (2000), Le Tourisme et l'Environnement en Europe, Office des Publications Officielles des Communautés Européennes, Luxemburg.

Buckley, R. (1994), "A Framework for Ecotourism". Annals of Tourism Research 21, 661-665.

Buckley, R. (2001), "Environmental Impacts". In: D.B. Weaver (ed.) The Encyclopedia of Ecotourism. Wallingford: $\mathrm{CAB}$ International. pp. 379-394.

Casagrandi, R. and Rinaldi, S. (2002), "A Theoretical Approach to Tourism Sustainability". International Institute for Applied Systems Analysis, Austria. Interim Report IR-02-051.

Eagles, P.F.J. (1995), "Understanding the Market for Sustainable Tourism". In: S.F. McCool and A.E. Watson (eds.) Linking Tourism, the Environment and Sustainability. Topical Volume of Compiled Papers from a Special Session of the Annual Meeting of the National Recreation and Park Association, 1994 October 12-14 Minneapolis, Report INT-GTR-323. Ogden, UT:US.

Fennell, D.A. (1999), "Ecotourism: An Introduction". Routledge, London.

Gössling, S. (2000), "Sustainable Tourism Development in Developing Countries: Some Aspects of Energy Use". Journal of Sustainable Tourism 8 (5), 410-425.

Hardy, A.L., Beeton, R.J.S. and Pearson, L. (2002), "Sustainable Tourism: An Overview of the Concept and Its Position in Relation to Conceptualizations of Tourism". Journal of Sustainable Tourism 10(6), 475-496.

Hall, C.M and Lew, A.A. (eds.). (1999), "Sustainable Tourism: A Geographical Perspective". Longman: London. between Kenyan and Romanian Nationals would also be vital in achieving the requisite results for the development of sustainable tourism in conservation of the environment.

Honey, M. (1999). "Ecotourism and Sustainable Development: Who owns Paradise?" Island Press.

Manning Ed., Dougherty D. T. (1995) Sustainable Tourism, University Cornell, Montreal.

McLaren, D. (1998). "Rethinking Tourism and EcoTravel: The Paving of Paradise and What You Can Do To Stop It". Kumarian Press, Connecticut.

Mowforth, M. and Munt, I. (1998), "Tourism and Sustainability: New Tourism in the Third World". Routledge, London.

Nedelea, A. (2003), Piaţa turistică, Ed. Didactică şi Pedagogică, Bucureşti.

Nedelea, A. (2003) Politici de marketing în turism, Ed. Economică, Bucureşti.

Parker, S. and Khare, A. (2005), Understanding Success Factors for Ensuring Sustainability in Ecotourism Development in Southern Africa. Journal of Ecotourism 4(1), 32-45.

Sindiga, I. (1999), "Tourism and African Development: Change and Challenge of Tourism in Kenya". African Studies Centre Research Series.

Stabler, M.J. (ed.) (1997), "Tourism and Sustainability: Principles to Practice". Wallingford: CAB International.

Stucki, E. - Le developpement équilibré du monde rurale en Europe, Sauvegarde de la nature, nr. 58/1992.

Telfer, D.J. (2002), Tourism and Regional Development Issues. In: R. Sharpley. And Telfer, D.J. (Eds.), Tourism and Development Concepts and Issues. Channelview Publications.

Ward, J., Hughey, K. and Urlich, S. (2002), "A Framework for Managing the Biophysical Effects of Tourism on the Natural Environment in New Zealand". Journal of Sustainable Tourism, 10(3), 239-259.

Watson, G. (1996) Tourist Carrying Capacity, Wiley.

World Tourism Organization. (2001), The Least Developed Countries and International Tourism, Background Note presented at the High Level Meeting on Tourism in LDC, Canary Island, March. 